\title{
The Reconstruction of the Reversal of the Burden of Proof Verificationin Corruption Delict
}

\author{
Soehartono Soemarto
}

\author{
Promotor : Prof. Dr. Made Sadhi Astuti, S.H., M.S. \\ Co-Promotor : Dr. Ismail Navianto, S.H., M.H. \\ Dr. Bambang Sugiri, S.H., M.S.
}

Doctoral Program, Law Faculty, Brawijaya University, Malang, Indonesia

E-mail: soehartono_sh@yahoo.com

\begin{abstract}
The reverse proof system adopted in the Act Number 31 of 1999 concerning the Eradication of Corruption as amended and supplemented by the Act Number 20 of 2001 Amendment to thye Act Number 31 of 1999 is a limited and balanced reverse verification system. This is contained in the general explanation of the Act. One of the reasons for the application of a reverse proof system into positive law in Indonesia is that Corruption is not only considered as a crime that is detrimental to certain parties but a crime that is a violation of social and economic rights and has a negative impact on many parties. If we examined from the side of the formulation, it is necessary to reconstruct or reformulate the articles that govern the reverse proof system as stated in the Act on Corruption. Reformulation needs to be done with several basic reasons. One of the reasons is, for example, the process of proceeding (criminal procedural law of corruption) only applies a reverse verification system during the trial. Therefore, through this paper, it is described how the reconstruction of the regulation of the reverse proof system of corruption in the future by using normative legal research. Construction of proof is reversed in order to investigate, investigate the corruption so there are several alternative ideas; First, on the substance of the law, which directs the formulation of the norm of burden of proof upside down with an emphasis on legislation policy in accordance with the 2003 United Nations Anti-Corruption Convention (KAK) as a characteristic of a combination of the "Common law" legal system and the "Civil Law" legal system". Second, the construction of the law enforcement structure, namely placing officials of the Corruption Eradication Commission (KPK) all the way to the regions, especially the provincial areas. Third, construction in the culture of society, reconstructed their perspective by way of providing massive, structured, and systematic education emphasizing that corruption are extraordinary crimes.
\end{abstract}

Keywords - Reconstruction, Corruption, Reverse Proof Verification.

\subsection{Background}

Corruption in Indonesia is still a serious problem and cannot be resolved properly. These problems can be observed from the increase of corruption cases every year, both from the number of cases that occur, the amount of state financial losses and in terms of the quality of criminal acts. Annual report results by the Indonesian Corruption Watch (ICW), on the completion of corruption cases in 2016, namely there were 482 Corruption Cases with the number of suspects 1,101 Suspects of Corruption Cases, and the value of State losses amounting to Rp. 1.47 Trillion. ${ }^{1}$ While for bribery cases there are 33 cases with a state loss value of Rp. 32.4 billion. The fraud at the office there are 3 Cases that cause a State loss value of Rp. 2.3 Billion and for Extortion there are 7 Cases with a total loss of Rp. 20.5 Billion. ${ }^{2}$

Another thing that can be confirmed related to the uncompleted of corruption cases in Indonesia is the result of a survey conducted by Political and Economic Risk Consultancy Ltd (PERC). ${ }^{3}$ The PERC survey results in 2010 put Indonesia as the most corrupt country in Asia Pacific. Meanwhile, Transparency International over the Bribe Payers Index (BPI), an index describing bribery practices carried out by the business community against

\footnotetext{
${ }^{1}$ Indonesia Corruption W atch (ICW) 2016 Annual Report, "Sowing the Spirit of Anti Corruption" (online), http://www.antikorupsi.org/, accessed on May 25 ${ }^{\text {th }}, 2017$,p. 17 ${ }^{2}$ Ibid, p. 21

${ }^{3}$ Political and Economic Risk Consultancy Ltd is a consulting company that specializes in examining and reviewing the issues of economic and business levels of countries in Asia. See Elwi Danil, The Concept of Corruption, Crime and Inclusion, (Jakarta: PT. Raja Grafindo Persada, 2011), p. 66-67
} 
state officials or public officials in a country) has revealed quite interesting facts. ${ }^{4}$

In 2011, BPI conducted a survey of 3,000 businessmen whoare running International business in 28 countries which ranked Indonesia 25 th out of 28 countries with a BPI of 7.1 from an average of 7.8..$^{5}$ The picture related to the index of bribery behavior has worsened, when correlated with data on the Corruption Perception Index released by Transparency International, as the data below 6 ::

Table.1: Indonesian Corruption Perception Index and IPK Rating (2004 - 2011)

\begin{tabular}{|c|c|c|}
\hline Year & $\begin{array}{c}\text { Corruption } \\
\text { Perception Index }\end{array}$ & Rank \\
\hline 2004 & 20 & $\begin{array}{c}113 \text { from } \\
146\end{array}$ \\
\hline 2005 & 22 & $\begin{array}{c}137 \\
\text { from159 }\end{array}$ \\
\hline 2006 & 24 & $\begin{array}{c}130 \text { from } \\
163\end{array}$ \\
\hline 2007 & 23 & $\begin{array}{c}143 \\
\text { from180 }\end{array}$ \\
\hline 2008 & 26 & $\begin{array}{c}126 \\
\text { from180 }\end{array}$ \\
\hline 2009 & 28 & $\begin{array}{c}111 \\
\text { from180 }\end{array}$ \\
\hline 2010 & 28 & $\begin{array}{l}110 \text { from } \\
178\end{array}$ \\
\hline 2011 & 30 & $\begin{array}{c}100 \text { from } \\
183\end{array}$ \\
\hline 2012 & 32 & $\begin{array}{c}118 \\
\text { from176 }\end{array}$ \\
\hline 2013 & 32 & $\begin{array}{c}114 \text { from } \\
117\end{array}$ \\
\hline 2014 & 34 & $\begin{array}{c}107 \text { from } \\
175\end{array}$ \\
\hline
\end{tabular}

Source: Secondary Legal Material made by the Author

Based on the data that has been proposed, it can be explained that the act of corruption is a crime that must be handled seriously. Corruption that always develops must also be followed by a handling strategy that is also developing. Especially if we look at the corruption that has been placed as one of the organized and transnational

${ }^{4}$ Transparency International is a Non Government Organitation (NGO) which was established to monitor the practices of Corruption throughout the world, this organization is headquartered in Berlin and has many representative offices in various countries. The organization issued a perception index of Corruption in the form of state rankings from the point of view of corrupt practices that occurred in these countries, and the index numbers were the result of polls from several corruption perception indices that had been carried out by other parties. Ibid, p. 66-67

${ }^{5}$ ToegarismanA, Eradicating Corruption in the Efficiency Paradigm, (Jakarta: PT. Kompas Media Nusantara, 2016), p. 2

${ }^{6}$ Ibid, p. 3 crimes by the United Nations Convention Against Transnational Organized Crime or the Convention on Transnational Organized Crime in 2000. This is based on the following considerations: ${ }^{7}$

1. The modus operandi of corruption has fused with the bureaucratic system in almost all countries including and not limited to Asian and African countries, and is carried out on a large scale by most high-ranking officials and even a president such as the Philippines, Nigeria and several other African countries;

2. Corruption has been proven to weaken the government system from within or we call as a dangerous virus and the cause of the process of decay in the performance of government and also weaken the democracy;

3. It is very difficult to eradicate corruption in a corrupt democratic system that requires extraordinary legal instruments to prevent and eradicate it;

4. Corruption is no longer a national problem of a country, but it is an inter-state problem or the relationship between two or more countries that requires active cooperation between countries that have an interest or are harmed due to corruption. This is due to the overwhelming evidence that corrupt as sets are placed in a country deemed safe by the perpetrator.

Observing the corruption as an extraordinary crime can also be seen from the explanation section in the Act No. 20 of 2001 concerning The Amendments of the Act No. 31 of 1999 concerning The Eradication of Corruption which states that:

"... considering that corruption in Indonesia occurs systematically and extensively so that it does not only harm the State's finances, but also violates the social and economic rights of the community at large, the eradication of corruption needs to be carried out extraordinary ..."

Corruption as an external crime can bring harm to the country. This loss is very likely to make it worse, more miserable, poorer, and further away from the achievement of the goals of the State, one of which is aimed at realizing a social justice for all the people of Indonesia. In the context of efforts to handle corruption, the law enforcement system is an important matter. Therefore, the

\footnotetext{
${ }^{7}$ Muhammad Yusuf, "Depriving Corruptor Assets: Solution for Eradicating Corruption in Indonesia". Gramedia, (Jakarta, 2003), p. 1-2
} 
factors that determine law enforcement must be considered, namely as follows: ${ }^{8}$

a. The legal factor itself, namely legislation;

b. Factors of law enforcement, namely parties that form or implement the law;

c. Factors of facilities or facilities that support the law enforcement;

d. Community factors, namely the environment in which the law applies or is created;

e. Cultural factors, namely as a result of work, creativity, taste, which is based on human intentions in the relationship of life.

Laws and regulations as one of the factors that determine law enforcement must certainly be strengthened. This can be observed from the enactment of The Act Number 31 of 1999 concerning The Eradication of Corruption and the Act Number 20 of 2001 The Amendment to the Act Number 31 of 1999 concerning The Eradication of Corruption.

Legislative arrangements for eradicating criminal acts of corruption that currently apply have provided room for the reversal of the burden of proof (omkering van bewijslast / the reversal of the burden of proof). Provisions concerning reverse court verification are contained in the Act Number 20 of 2001 of the Amendment to the Act Number 31 of 1999 concerning The Eradication of Corruption Crimes as stated in: Article $12 \mathrm{~B}$ paragraph (1) letter a; Article 37; Article 37 A paragraph (1) and Paragraph (2); Article 38 A; Article 38 B Paragraph (1) and Paragraph (2).

The reversal of the burden of proof system in the Corruption Act in Indonesia is a limited and balanced reverse verification system. This is contained in the general explanation of the Act No. 31 of 1999 concerning The Eradication of Corruption, which states: ${ }^{9}$

"... this law also applies limited and balanced of the reversal of the burden of proof, namely the defendant has the right to prove that he did not commit a criminal act of corruption and is obliged to provide information about all of his property and the assets of his wife or husband, children and property. every person or corporation that is suspected of having a relationship with the case in question, and the public prosecutor remains obliged to prove his charge."

There is a limited and balanced reverse verification system against certain offenses and also regarding the seizure of the results of corruption as a form

\footnotetext{
${ }^{8}$ Soekanto.S, Introduction to Sociology of Law, (Jakarta: Rajawali Pers, 2008), p. 253-268

${ }^{9}$ General Elucidation of the Act No. 31 of 1999 concerning Eradication of Corruption
}

of good will and state administrators in eradicating corruption as well as an attempt to recover state losses due to criminal acts of corruption. One of the reasons for the implementation of the reversal of the burden of proofsystem into positive law in Indonesia is that the Corruption include violations of the social and economic rights of the community at large which damage the national economic order and reduce the dignity of the nation in international forums, therefore it must be handled extraordinarily based on specific regulations (lexspecialis) governing this matter. It is in line with BaharuddinLopa opinion, that: ${ }^{10}$

"... it is time for us to apply the reversal of the burden of proofas is applicable in certain countries, especially in Malaysia, Singapore and Hong Kong. Since implementing a reversed verification system, these countries have become much less corrupt than before. After this reverse proofing system has been implemented in general, people in the country are afraid of corruption. Because, it is difficult to avoid being investigated, if it is proven that it is corrupt, such as accepting or giving a bribe, the act itself is seen as corruptly gratification, unless the opposite can be proven (unless the contrary is proved). "

Even though the use of the reversal of the burden of proof(omkering van bewijslast) was also criticized because it was deemed to contain the principles of "presumptions of corruption" which were contrary to human rights and other legal principles, such as "presumptions of Innocence" and "Non self-incriminations". In addition, it is realized that the condition of law enforcement is still not perfect and has the same vision in eradicating criminal acts of corruption, so the use of the reversal of the burden of proofis feared to cause diseases or forms of new criminal acts such as extortion. ${ }^{11}$

Furthermore, if we observed from the side of the legal formulation, it is necessary to reconstruct or reformulate the articles governing the reversal of the burden of proofsystem as stated in the Act Number 31 of 1999 concerning The Eradication of Corruption and the Act Number 20 of 2001 of The Amendments to the Act Number 31 of 1999 concerning the Eradication of Corruption. Reformulation needs to be done with several basic reasons.

\footnotetext{
${ }^{10}$ Baharuddin Lopa, Corruption and Law Enforcement, (Jakarta: PT. Kompas, 2001),p. 86

${ }^{11}$ Martiman Prodjohamidjojo, Application of Reversed Proof in Corruption Delict, (Bandung: CV. Mandar Forward, 2001), p. 108.
} 
The implementation of the reversal of the burden of proofsystem cannot run optimally. The process of the proceedings (criminal procedural law of criminal acts of corruption) only applies a reverse verification system during the trial. The new reverse proofing system runs effectively since the Public Prosecutor submits case files to the panel of judges that will try the defendant's case. The rescue of State assets / assets that should be allegedly corrupted by the Defendant is too late, the complexity of the verification process in court, and hampering the realization of a more Integrated Criminal Justice System.

For this reason, it still needs to be studied comprehensively, so that the implementation process can be carried out in an integrated manner in the crime prevention / crime (criminal politic) system of corruption, as an effort to conduct a renewal to the criminal procedural law, studies in applying the reversal of the burden of proof(Omkering van bewijslast).

\subsection{Research Problems}

Based on a number of points that have been identified in the background, the legal issues that need to be answered are related to how the reconstruction of the reversal of the burden of proofsystem in corruption cases in the future.

\subsection{Theoretical Framework and Conceptual} Framework

\subsubsection{The Criminal Purpose Theory}

The purpose theory as Theological Theory and combined theory as an integrative view within the goal of punishment assume that punishment has a structural purpose, in which both theories combine the Utilitarian view with the Retributivist view. The Utilitarian's view which states that the purpose of punishment must have beneficial and demonstrable consequences and the view of retributivists which state that justice can be achieved if the purpose of the Theological is carried out using a measure of principles of justice. ${ }^{12}$

Some theories related to the purpose of punishment are as follows:

a. Absolute Theory / Retribution

According to this theory the criminal is imposed solely because of someone who has committed a crime.

b. Objective / Relative Theory

The purpose theory views punishment as something that can be used to achieve utilization, both with regard to the guilty and related to the outside world,

\footnotetext{
${ }^{12}$ Muladi. The Conditional og Criminal Institution. (Bandung: Alumni, 2002) p. 45
}

for example by isolating and repairing criminals or preventing potential criminals, will make the world a better place. ${ }^{13}$ This purpose theory seeks to realize order in society. ${ }^{14}$ Regarding to this criminal objectives for the prevention of crime, it is usually divided into two terms, namely:

i. Special prevention (specialepreventie)

ii. General prevention (GeneralePrevenie)

c. Combined Theory

Combined theory is a combination of relative theory. According to the combined theory, the criminal purpose is always to repay criminals' wrong action and also intended to protect the public by realizing order with the provision that criminal weight cannot exceed the fair retribution limit. ${ }^{15}$

\subsubsection{Criminal Law Policy Theory}

Criminal law policy (penal policy) is part of criminal policy (criminal policy) and is an integral part of social policy. ${ }^{16}$ According to Marc Ancel, criminal policy is the rational organization of the control of crime by society. Similar understanding was also given by Sudarto who defined criminal policies as a rational effort of the community in overcoming crime. ${ }^{17}$ Then by G.P. Hoefnagels, criminal policy is defined as the rational organization of social reaction to crime. ${ }^{18}$ In addition to this definition, Hoefnagels also put forward various other illustrative definitions of criminal policy, namely:

a. Criminal Policy is the science of responses;

b. Criminal Policy is the science of crime prevention;

c. Criminal Policy is a policy of designating human behavior as crime;

d. Criminal Policy is a total rational of responses to crime. ${ }^{19}$

According to Marc Ancel's view, the scope of criminal policy contained the use of criminal legal facilities (non-penal policy). Conceptually, this criminal policy is an integral part of efforts to protect society (social defense) and efforts to achieve the social welfare. ${ }^{20}$ Therefore, the most important goal of the criminal policy is social protection to achieve social welfare. Based on this understanding, in a broad scope, this criminal policy is

\footnotetext{
${ }^{13}$ Muladi, Op.Cit., p. 55

${ }^{14}$ Muladi and BardaNawawiArief, Op.Cit., p. 78

${ }^{15}$ Samosir, Djisma, The Criminal Function of Prison in Criminal System in Indonesia(Bandung: Bina, Cipta, 1992), p. 71-72

${ }^{16}$ Marc Ancel, Social Defense: A Modern Approach to Criminal Problems, (Routledge \& Kegan Paul, London; 1965), p. 209

${ }^{17}$ Sudarto, Law and Criminal Law, (Alumni, Bandung; 1986) p. 38

${ }^{18}$ G. Peter Hoefnagels, The Others Side of Criminology; An Inversions of the Concept of Crime, (Kluwer-Deventer, Holland, 1973), p. 57

${ }^{19}$ Ibid, p.. 57,99,100

${ }^{20}$ BardaNawawiArief, $O p$. cit, p. 2
} 
essentially an integral part of social policy, namely policies or efforts to achieve social welfare. ${ }^{21}$

Furthermore, in the context of criminal law policy (reason policy), according to Marc Ancel penal policy are: both a science and an art, of which the practical purposes, ultimately, are to enable the positive rules better formulated and to guide not only the legislator who has to draft criminal statutes, but the court by which they are applied and the prison administration which gives practical effect to the court's decision. ${ }^{22}$ (a science as well as art which ultimately has a practical purpose to enable the regulation of positive law to be better formulated and to provide guidance not only to the lawmakers, but also to the courts that apply the law and also to the organizers or implementers of court decisions).

Then according to A. Mulder the criminal law policy is matched with the term strafrechtspolitiek which means as a policy line to determine:

1. how far the applicable criminal provisions need to be changed or renewed

2. what can be done to prevent criminal acts

3. in which way of investigations, prosecutions, trials and criminal acts must be carried out. ${ }^{23}$

Considering the importance of formulative policies in ensuring legal certainty, efforts to renew the criminal law need to be carried out so that their implementation can be carried out effectively while paying attention to moral values and a sense of justice and benefit in accordance with legal developments in society or with other laws. So, that it can realize an integrated criminal justice system.

\subsubsection{Theory of the Criminal Justice System}

The definition of the criminal justice system or also commonly referred to as the law enforcement system. ${ }^{24}$ The word system in the criminal justice system is associated with the word integrated. This is because in terms of the system contained the meaning of integration (coordination). The Criminal Justice System (SPP) is a component of criminal justice that is interrelated with each other and works to achieve the same goal, namely to overcome crime to the extent that can be tolerated by the community. ${ }^{25}$

\footnotetext{
${ }^{21}$ Ibid, p. 3

${ }^{22}$ Marc Ancel, Op.cit. p. 4-5

${ }^{23}$ BardaNawawiArief, Op.cit, p. 23

${ }^{24}$ Bryan A. Garner, Black's Law Dictionary, Eight Edition, West Publishing CO., United States, 2004. p. 901.

${ }^{25}$ Muladi, Kapita Selekta Criminal Justice System, Board of Publishers of Diponegoro University, Semarang, 1995. p. 1.
}

The criminal justice system has its own characteristics that distinguish it from other systems, including:

1. Open System

The criminal justice system in its application will always experience an interface that is in the form of interaction, interconnection and interdependence of the environment in the ranks of the community, namely in the fields of: economics, politics, education and technology, as well as the criminal justice sub-system itself (the sub system of criminal justice systems ). ${ }^{26}$

2. Having a goal

There are 3 general objectives of the criminal justice system. The short-term objective of the criminal justice system is that the offender is expected to be aware of his actions so that he does not commit another crime. The mediumterm objective is the realization of an orderly, safe and conducive atmosphere in people's lives. The long-term goal of the criminal justice system is to create a comprehensive level of welfare among the community.

3. Value Transformation

Value transformation in the sense of the criminal justice system is a mechanism of work operation for each of its components, and must include values in every action and policy carried out, such as truth values, values of fairness, values of honesty, virtue and propriety. ${ }^{27}$

4. The existence of a control mechanism

The control mechanism is a form of supervision over the response to crime (repressive). The criminal justice system can be a legal tool that can be used in tackling various forms of crime which are part of efforts to protect the community. ${ }^{28}$

According to Hebert L. Packer, there are two processes in the criminal justice system in Indonesia, namely: ${ }^{29}$

1. Crime Control Model, namely the perpetrator of the crime is seen as an object in the examination. In this model legislative power is very dominant and is a type of affirmative model that

\footnotetext{
${ }^{26}$ Sidik Sunaryo, Ibid. p. 255

${ }^{27}$ Mahrus Ali, The Progressive Criminal Justice System: Some Alternative in Criminal Law Enforcement, Journal of Law No. 2 Vol. 14 128. Http://www.e-jurnal.com/2013/12/sistem-pidana-progressive-.html. (Accessed on September $29^{\text {th }} 2015$ at 2:35 p.m.)

${ }^{28} \mathrm{Ibid}:$ : 28 . http://www.e-jurnal.com/2013/12/sistemperadilan-pidana-progresif.html. (Accessed on September $29^{\text {th }} 2015$ at 2:35 p.m.)

${ }^{29}$ Romli Atmasasmita, Op Cit. p. 12
} 
emphasizes efficiency and control of power in every corner of the criminal justice process.

2. Due Process Model, believes that the perpetrators are viewed as subjects in the examination.

\subsubsection{The Proof Verification Theory}

The nature of proof in criminal law is a very important part, which if explained can be said that the verification is carried out through a judicial process so that it will determine whether a person can be punished (veroordeling) because the results of the trial are legally and convincingly proven to have committed a crime, then the defendant can be released from the indictment if it is not proven to have committed a crime. ${ }^{30}$ Etymologically, the word proof comes from the word "proof" which means something that is sufficient to show the truth of a thing. Proof is evidence. Proving is the same as giving (showing) evidence, doing something as truth, carrying out, signifying, watching and convincing. ${ }^{31}$

Juridically, it is explained by M. YahyaHarahap that the proof is the provisions containing inheritance and guidelines on the methods justified by the Law and guidelines on ways that are justified by the Law to prove the offense that was charged to the defendant. The evidence also regulates the evidence that the law justifies and regulates the evidence that may be used by the judge to prove the defendant's guilt. The court may not at will and arbitrarily prove the defendant's guilt. ${ }^{32}$

The law of proof can be categorized into a form of general and specific proof of law. ${ }^{33}$ Furthermore, in order to implement proof in Indonesian criminal law, there are several legal theories of proof. Therefore, theoretically there are 3 (three) theories of proof, namely as follows:

a. The Legal Theory of Proof in the Law Positively.

According to this theory, the positive proof law depends on the evidence as stated in the law. The law has determined which evidence that can be used by the Judge to make a consideration before deciding whether or not the case is being tried. ${ }^{34}$

b. The Legal Theory of Proof According to Judge's Belief.

The thing that underlies the birth of this theory is the factor of the judge's conviction, the judge can impose a decision based on mere "Belief" by not being related to a regulation. Furthermore, the legal theory of evidence based on the conviction of the judge has 2 forms of polarization, the first:

\footnotetext{
${ }^{30}$ LilikMulyadi, Op.Cit.,p 76.

${ }^{31}$ Soedirjo, Prosecutor and Judge in the Criminal Process, (Jakarta: CV. Akademika Pressido, 1985), p. 47. .

${ }^{32}$ LilikMulyadi, Op.Cit.,p 85.

${ }^{33}$ LilikMulyadi, Ibid., p. 90.

${ }^{34}$ LilikMulyadi, Ibid., p. 93.
}

the legal theory of proving "Conviction In time", the defendant's fault depends on mere "Belief", so the judge is not bound by a rule, thus the verdict appeared here is subjective. ${ }^{35}$

c. The Legal Theory of Proof in Law Negatively. The legal theory of evidence according to negative law stipulates that a judge may only impose a criminal offense against the defendant if the evidence is limited by law and supported by the existence of a judge's belief in the existence of these tools. In essence, the legal theory of proof according to the law is negatively a combination of legal theory of evidence according to the law positively and the legal theory of proof based on the judge's conviction.

Based on the explanation of these three evidentiary theories, theoretically and normatively the law of proof in Indonesia uses the theory of proof law in a negative manner. Even though in practice the passing of justice and the appearance of Article 183 of the Criminal Procedure Code begins to shift the proof of the legal theory of proof according to the law positively that the element of "at least two instruments of evidence" is a dominating aspect, while the element of "judge's conviction" is only "complementary""Because in the absence of these aspects the decision will not be canceled, and the practice is only" corrected "and" added "to the appeal level by the High Court or at the appeal level by the Supreme Court of the Republic of Indonesia. ${ }^{36}$

Then in the context of proof of corruption cases are known to be reversed. The load theory of reversed proof of balance is probably a theoretical attempt to determine the solution to the application of an inverse proof burden in eradicating corruption which is difficult to prove, especially concerning the origin/source of the as sets of the Defendant. ${ }^{37}$

Corruption criminal law as a criminal law originates from a special law on criminal law, in addition containing material criminal law as well as formal criminal law. As a special formal criminal law only contains a small portion of criminal procedural law, namely special matters that are considered important as exceptions contained in the Criminal Procedure Code, while beyond the specific matters, formal criminal law applies as regulated in the Criminal Procedure Code as a current codification of formal criminal law. ${ }^{38}$

${ }^{35}$ LilikMulyadi, Ibid.,p. 95.

\footnotetext{
${ }^{36}$ LilikMulyadi, Op.Cit.,p. 100.

${ }^{37}$ LilikMulyadi, Ibid., p. 114

${ }^{38}$ Adami Chazawi, The Material and Corruption Criminal Law in

Indonesia, (Malang: Bayumedia, 2005), p. 379.
} 
Article 26 of the Act Number 31 of 1999 concerning the Eradication of Corruption stipulates that investigations, prosecutions, and hearings at court proceedings are carried out based on the applicable procedural law, unless otherwise stipulated in this law. That is, the procedural law governed by the corruption law is only about specific or certain matters, whereas in general or matters relating to procedural law that are not regulated in the corruption law still apply criminal procedural law in the Criminal Procedure Code.

Regarding the burden of proof in criminal law corruption, there are several theories about the proof loading system. Assessed from the perspective of known criminal law science there are 3 (three) theories about the burden of proof, namely: the burden of proof on the public prosecutor, the burden of proof on the defendant and the burden of proof of balance. According to LilikMulyadi, if the three polarization of the burden of proof theory is examined from the benchmarks of the prosecutor and the defendant, actually this proof of burden theory can be divided into 2 (two) categorizations, namely: ${ }^{39}$

First, the usual or conventional proof load system. Second, the reverse proof burden theory which in this aspect can be divided into absolute or pure reverse proof burden theory that the defendant and / or his legal counsel prove the defendant's innocence. Then the inverse proof of burden theory is limited and balanced in the sense that the defendant and prosecutor prove each other's guilt and innocence.

In the context of the universal criminal case that applies in the world, the obligation to prove the indictment charged to the suspect is to the public prosecutor. This proof is also called ordinary or "conventional" evidence in this case the public prosecutor who proves the defendant's fault (actoriincumbit onus probandi / actorenonprobante, reusabsolvitur). ${ }^{40}$

Reverse proof system is a proof system that is beyond the theoretical prevalence of proof in universal criminal procedural law, in criminal procedural law both in the Continental European and Anglo-Saxon systems, recognizing proof by still imposing obligations on the public prosecutor. However, in certain cases are allowed to apply with a differential mechanism, namely the Reversal Proof System or known as "Reversal of Burden Proof" (Omkering van Bewijslast). That is not done in its entirety, but has minimal limits not to do a destruction of the protection and appreciation of human rights, especially the suspect / defendant's rights .41

\footnotetext{
${ }^{39}$ LilikMulyadi, Op.cit, p. 103-104

${ }^{40}$ Eddy OS Hiarriej, Inverted Proof of Corruption, (Yogyakarta: Fiat Justicia Bulletin, Faculty of Law UGM, 2012), p. 2.
}

\footnotetext{
${ }^{41}$ Indriyanto Seno Adji, Op.cit, p. 328.
}

This Reverse proof system is divided into two, namely: inverted proof that is absolute (pure / absolute) and reversed proof which is limited and balanced (affirmative defense). According to Eddy OS Hiarriej: ${ }^{42}$

"The absolute reversal of the burden of proof is that the defendant proves that he is innocent as an obligation. There are only two possibilities, whether the accused cannot prove that he is innocent or the defendant can prove that he is innocent. "

By referring to the opinions above, it can be concluded that the reversed proof in pure / absolute form is a proof charged to the defendant to prove his innocence and applied to all corruption offenses. This reverse proof system that has never been applied in any country because it is considered to violate the principle of presumption of innocence, the principle of not self-blame and the right to silence (Right to Remain Silent). ${ }^{43}$

Reverse Proof of Provisions contained in Article 37 of the Act No. 31 of 1999, said to be a "shifting" or a shift in proof rather than a "reversal" because in Article 37, the evidence made by the defendant to prove that he is not corrupt is only a relative right and if the defendant uses this right, the public prosecutor is still obliged to prove his charge. This is what became known as balanced proof. This can be seen in the general explanation of the Act No. 31 of $1999 .{ }^{44}$ Then there is also an explanation in Article 37 of the Act No. 31 of 1999.45

Indriyanto Seno Adji explained that related to this matter, it was said to be limited because the reverse proofing system could not be carried out on all corruption offenses so it must be limited to certain offenses. This implies that the application of reverse evidence for all corruption offenses will violate the defendants' rights and also be easier for the defendant to be free from the law because the perpetrators of criminal acts of corruption are

${ }^{42}$ Eddy OS Hiarriei, Op.cit, p. 2.

${ }^{43}$ Loekman Wiriadinata, Reverse Verification Problem in the New Anti-Corruption Bill, Law and Justice Magazine, Number 6 September 1, 1970, p. 20. Quoted by Andi Hamzah, Corruption Eradication is Reviewed .... Op. Cit,p. 63.

${ }^{44}$ General Elucidation of the Act No. 31 of 1999, which states: "In addition, this law also applies limited or balanced inverse proof verification that the defendant has the right to prove that he has not committed a criminal act of corruption and is obliged to provide information about all of his property and wife or husband's property, children and property of any person or corporation that is suspected of having a relationship with the case in question, and the public prosecutor remains obliged to provehis charge."

45 General Elucidation of Article 37 of the Act No. 31 of 1999 which states: "... According to this provision the defendant can prove that he did not commit a criminal act of corruption. If the defendant can prove this does not mean he is proven to be corrupt, because the public prosecut or is still obliged to prove his charge. The provisions of this Article are limited inverse evidence, because the Prosecut or is still obliged to prove his charges. " 
generally carried out by people who have a high level of education, so that the perpetrator understands the problem better. Then even though the defendant has proven his innocence or unable to prove his innocence but the public prosecutor is still given the opportunity to prove his indictment, this is in the opinion of the writer to be balanced, because the defendant and the public prosecutor are equally given the opportunity to prove each other and what is proven by each party is also different.

\subsubsection{The Concept of Corruption}

The concept of corruption in law, beforehand regarding the elements of corruption according to Sudartoare: 46

1. Doing an act of enriching yourself, others or an entity. The act of "enriching" means doing anything, for example taking, signing a contract and so on, so that the perpetrators get richer;

2. The act is against the law. "Against the law" in this case is defined both formally and materially. This element needs proof because it is explicitly stated in the formulation of the offense;

3. The act directly or indirectly is detrimental to the state finances and / or the country's economy, or the act is known or deserves to be suspected of detrimental to the state's finances or the country's economy.

The concept of corruption is regulated in the Corruption Eradication Act which applies according to the Act No. 31 of 1999 which was amended and supplemented in the Act No. 20 of 2001 concerning Eradication of Corruption. If the law is replaced in the future by the Corruption Eradication Act with a new concept (there is a renewal of the concept), then the concept of criminal acts of corruption should adjust to the latest legal requirements as well as the dynamics that develop in the lives of Indonesian society, as well as the formulation not criminal listed in the applicable Corruption Eradication Act.

\section{METHOD}

\subsection{Types of Research and Approaches}

The type of research used in this journal is A legal research, namely the process of finding legal rules, legal principles, as well as legal doctrines in order to answer the legal issues at hand. ${ }^{47}$ Referring to the substance, this legal research includes normative legal research, namely legal research conducted by examining legal material (literature study) or secondary data.While the approach used is a

${ }^{46}$ Sudarto in EviHaertabti, Criminal Act of Corruption, (SinarGrafika, 2005) p. 18

${ }^{47}$ Peter Mahmud Marzuki, Legsl Research (Jakarta: Prenada Media, 2005), p. 35. statute approach, a conceptual approach, a case approach and a comparative approach. ${ }^{48}$

\subsection{Types and Sources of Legal Material}

The legal material used in this study consists of three (3) legal materials as follows:

a. Primary legal material

Primary legal material is the main legal material that is the subject of this research study. Primary legal material consists of positive law rules sorted according to hierarchy consisting of:

1) The 1945 Constitution of the Republic of Indonesia;

2) Decree of the People's Consultative Assembly of the Republic of Indonesia Number: XI / 1998 concerning State Administrators that are Clean and Free of Corruption, Collusion and Nepotism;

3) Act Number 24 / PRP / 1960 concerning Investigation, Prosecution and Examination of Corruption Crimes which supersedes the Rule of War Ruler Number PRT / PERPU / 013/1958;

4) Act Number 1 Year 1946 concerning Criminal Law Regulations jo. Act Number 73 of 1958 concerning Stating the Applicability of Act No. 1 of 1946 for the entire territory of the Republic of Indonesia and amending the Criminal Code. Jo. Act Number 4 of 1976 concerning Changes and Additions of Several Articles in the Penal Code of Criminal Law Related to the Expansion of the Applicability of Criminal Legislation (which is better known as the Penal Code / KUHP);

5) Act Number 8 of 1981 concerning Indonesian Criminal Procedure Law (KUHAP);

6) Act Number 3 of 1971 concerning the Eradication of Corruption;

7) Act Number 28 of 1999 concerning State Administrators that are Clean and Free of Corruption, Collusion and Nepotism;

8) Act Number 30 of 1999 concerning the Corruption Eradication Commission;

9) Act Number 31 of 1999 concerning Eradication of Corruption;

10) Act Number 20 of 2001 concerning Amendments to the Act Number 31 of 1999 concerning Eradication of Corruption; 
11) Act Number 12 of 1995 concerning Correctional;

12) Act Number 2 of 2002 concerning the National Police of the Republic of Indonesia;

13) Act Number 16 of 2004 concerning the Prosecutor's Office of the Republic of Indonesia;

14) Act Number 46 of 2009 concerning the Corruption Court;

15) Act Number 48 of 2009 concerning Judicial Power;

16) Other relevant laws and regulations.

b. Secondary Legal Material

Secondary legal materials are materials that are closely related to primary legal materials, so they can help describe and analyze and to understand primary legal materials. Secondary legal materials in this study were obtained from doctrines, theories, opinions of existing legal experts; in the literature, both from textbooks, journals, scientific writings and information in print and electronic media.

\section{c. Tertiary Legal Material}

It is a legal material taken from the Indonesian general dictionary, English-Indonesian dictionary, legal dictionary and encyclopedia which provides an understanding of the decisions of criminal judges, the criminal justice system and criminal procedural law, especially those relating to the subject matter.

\subsection{Legal Material Searching Techniques}

Thus, the legal material collection techniques used in this study are library study techniques (library research) which will collect, study and review legal materials that have relevance to the problems formulated in this study, both against primary legal materials, secondary legal materials and tertiary legal material.

\subsection{Legal Material Analysis Techniques}

Legal material analys is technique uses qualitative descriptive analysis techniques. ${ }^{49}$ From the results of the analysis, then the interpretation of the law is carried out through the help of methods or teachings on interpretation. The interpretation method used in this study is: grammatical interpretation; systematic interpretation; and futuristic interpretation.

${ }^{49}$ According to Winary oSurakhmad as quoted by Soejono and Abdurrahman in the book of LegalResearch Methods, (Jakarta:

RinekaCipta, 2003),p. 23, it is said that essentially every research has a descriptive nature, and each research also uses an analytical process. Therefore, descriptive and analytical methods have an important role in research, so that these two aspects will be carried out by researchers in this dissertation research.
III. RESULT AND DISCUSSIONS

3.1 The Arrangement of the Reverse Proof Verification System for Corruption in the Future

Reversed Proof Verification of Provisions in Article 31 paragraph (8) of the United Nations AntiCorruption Convention (KAK) is intended to freeze, seize, and confiscate perpetrators of corruption. This provision can be a consideration for countries that are convention participants to oblige an offender to explain the legal source of the results that allegedly originated from corruption or other assets that may be subject to confiscation, as faras these conditions are still relevant to the principles the legal basis of a country, as well as consistent with the judicial process and other judicial processes. ${ }^{50}$

Reversed Proof Verificationin the provisions of Article 53 sub-paragraph (b) of the KAK, expressly states that: "Take measures that may be necessary to allow the court to order those who have committed crimes established under this convention to pay compensation or compensation to participating countries others who have been harmed by these crimes." 51

KAK in 2003 which regulates the return of assets resulting from corruption through procedural freezing, seizure, and confiscation of the perpetrators of corruption using a balanced probability theory derived in terms of ownership of assets which are assets resulting from corruption and still maintain the theory in a very high position in the matter of deprivation of independence of a suspect. ${ }^{52}$

The legal politics of Indonesia's legislative policy on the corruption offenses contained in the Act No.31 of 1999 Jo Act No.20 of 2001 is relatively not as complete as the arrangements in the $2003 \mathrm{KAK}$. There is a lack of clarity and synchronization in the formulation of inverse proof verification system norms. In the legislative policy Act No.20 of 2001. The lack of clarity and lack of synchrony is that the normalized inverse system has "existed", but in practice it is "non-existent" because it cannot be implemented at the level of its application.

Uncertainty and lack of synchronization in the formulation of an inverse proof system is also pointed to the mistakes of people as stipulated in Article 37 of the Act No.31 of 1999 Jo Act No.20 of 2001 which, if analyzed deeper, has implications for Human Rights (HAM), which in the practice of justice in Indonesia prioritizes the principle of presumption of innocence, and also contradicts the criminal procedural law that the defendant is not charged with showing proof or evidence. ${ }^{53}$

\footnotetext{
${ }^{50}$ LilikMulyadi., Op.Cit, p. 252

${ }^{51}$ Ibid.

${ }^{52}$ Ibid, p. 254.

${ }^{53}$ Ibid,p. 255.
} 
It is necessary to improve this provision on the formulation of reverse proof verification to be in accordance with the eradication of corruption after the 2003 KAK which Indonesia has ratified in the Act No. 7 of 2006. So that the formulation of these norms can be in line with the perspective of Human Rights (HAM), and not contrary to the provisions of criminal procedural law both in the theoretical and practical levels. ${ }^{54}$

If further analyzed, the Act on Eradication and Corruption which currently applies in Indonesia if it is in synergy with the provisions of the $2003 \mathrm{KAK}$ is essentially giving matters that are oriented to the following dimensions: ${ }^{55}$

a. Political Laws of The legislative policy in the Criminal Act in Indonesia, especially those that regulate the reverse proof verification system by referring to the $2003 \mathrm{KAK}$, is in accordance with international legal instruments on the eradication of corruption. In essence, from theoretical and practical studies, eradicating criminal acts of corruption must involve all potential and elements, institutions and community participation. The approach in the 2003 TOR is preventive, repressive and restorative with a substantial benchmark of shifting perspectives from law enforcement that only focuses on the criminal regime, namely the punishment of perpetrators through retributive philosophy shifts to a civil regime approach with the emphas is on restorative return of assets. Consequently, the formulation of inverse proof burden norms in this legislation policy is one of the solutions or an adequate alternative in the context of tackling cases of corruption which have recently become more prevalent in the community.

b. Legal politics is the formulation of the burden of proof norms upside down with an emphasis on legislation policies in accordance with KAK 2003 as a characteristic of a combination of the legal system "Common law" with the legal system "Civil Law", so that it will enrich the substance of the legislation in Indonesia if we examined from a political perspective statutory law in Indonesia. Therefore, with the combination of the two legal systems, it is expected that there will be a mix of positive aspects of each legal system concerned by minimizing the negative aspects of the legal system.

c. Legislation policy in accordance with KAK 2003 has shifted the dimension of law enforcement to eradicate corruption, which initially through the Traditional Criminal Law regime which emphasized retribution, entrapment, and benefit for the wider community, shifted to the dimension of the civil law regime. In essence, the philosophy of eradicating corruption in the 2003 KAK emphasizes more on the flow dimension of utilitarian philosophy which focuses on a combination of distributive justice and cumulative justice.

The alternative polarization of the burden of proof verification at the court after KAK 2003 in the provisions of the Corruption Act, can be stated in the form of norms as follows:

1. Against the Reverse Proof verification contained in Article 37 paragraph (1) and paragraph (2) of the Act No. 20 of 2001, can be formulated with alternative formulation of norm formulation as follows:

a. The suspect is obliged to provide information to the investigator about the origin of all his property and the assets of his wife or husband, children, and property of any persons or corporation suspected of having a relationship with the case alleged to him.

b. In the event that a suspect at the investigation stage cannot prove the origin of wealth that is not balanced with his income or source of additional wealth, then the information referred to in paragraph (1) is used to strengthen the existing evidence, thus accelerating the investigation process and at the prosecution stage, it will make it easier for the public prosecutor to prepare the charges.

c. Provisions as referred to in paragraph (1) and paragraph (2) constitute criminal acts or principal cases as referred to in Article 2, Article 3, Article 4, Article 13, Article 14, Article 15, and Article 16 of the Act Number 31 of 1999 concerning Eradication of Corruption and Article 5 to Article 12 of this Act, so that the public prosecutor remains obliged to prove his charges.

2. Regarding the provisions contained in Article 38 A of the Act No.20 of 2001, the provisions in the article should be modified or adjusted. The polarization of the reverse proofing arrangement in the formulation of norms in the article, can be formulated as an alternative formulation of the norm formulation arrangement as follows: 
"Proof as referred to in Article 12B paragraph

(1) is carried out to the suspect at the investigation level".

The conception of the article above determines that the proof of the Gratification offense that is allegedly bribed should be able to be done when the perpetrator is still a suspect or in other words the proof of whether or not the gratuity is not a bribe from the investigation stage. This needs to be done to minimize the occurrence of Money Laundering (TPPU).

3. Against the inverse proof verification in the provisions of Article 38B paragraph (1) of the Act No.20 of 2001, an alternative formulation of the norm formulation arrangement as follows:

Every person charged with committing one of the acts of corruption as referred to in Article 2, Article 3, Article 4, Article 13, Article 14, Article 15, and Article 16 of the Act Number 31 of 1999 concerning Eradication of Corruption and Article 5 through Article 12 of this Act, must prove the opposite of his property and the origin of his assets that have not been charged, but also allegedly derived from criminal acts of corruption. The conception of the article above determines that the Defendant is also obliged to prove the origin of his assets that have not been charged, but allegedly originated from Corruption. Unlike the provisions of the corruption offense at this time, which is based on the provisions of Article 38B paragraph (1) is only aimed at the principal corruption, and for the offense of gratification the public prosecutor cannot seize the assets of the perpetrator and vice versa the defendant is not charged with inverted evidence of the origin of the assets that have not been charged but allegedly originating from criminal acts of corruption.

\subsection{Reconstruction of Regulations Regarding} the Reverse Proofing Verification System in the Corruption Act in Indonesia in order to be Applied Optimally

Reverse proof verification system as stipulated in the Act No. 31 of 1999 concerning Eradication of Corruption and Act No. 20 of 2001 concerning Amendments to Act No. 31 of 1999 concerning the Eradication of Criminal Acts of Corruption there has been a lack of clarity and inconsistency in formulating norms of reversing the burden of proof so that at the level of implementation of this system has not been carried out optimally. This is due to various factors as described in the previous section. Therefore, improvements to the formulation of the provisions of the inverse proof system must be carried out.

The arrangements regarding the reverse proofing system must be sought by the proper concept or formulation as well as its formulation in accordance with the 2003 Anti-Corruption United Nations Convention (UNCAC), 2003 which has been ratified by ActNumber 7 of the Year 2006, so that the aim of the adoption of this system can be achieved optimally, not in conflict with human rights and is expected to minimize corruption and be effective in restoring state financial losses.

Alternative arrangements for reverse proofing systems in the provisions of the law on eradicating corruption, among others, can be done by changing the norms of the reversal of the evidentiary burden contained in Article $37 \mathrm{~A}$, should regulate the implications or impact on the principal case in the event the defendant is able to prove the balance between property the object belonging to the defendant with his income or property obtained from a legitimate source and regarding the status of property as evidenced by the defendant must be clarified that if the defendant succeeds in proving the balance between the property of the defendant and his income or property obtained from a legitimate source then the property the object cannot be subject to seizure and vice versa.

According to MardjonoReksodiputro, an inverse verification system like this should also be able to be carried out on the property of the defendant who previously, considering that generally people commit corruption not only once, the increase in the assets of the defendant must also be proven. ${ }^{56}$ Then in the opinion of the writer the evidence made by the defendant in this provision should be made at the time of examination of the defendant's statement because the examination of the defendant's information is still in the series of proof of this matter which should also be corrected in the provisions of Article 38 B paragraph (4).

The provisions of Article 38 B paragraph (4) which regulates that the property referred to in paragraph (1) does not originate from a criminal act of corruption filed by the defendant when reading his defense should be revised. The proof is better done when examining the defendant's statement because the examination of the defendant's information is still in the series of proof that this aims to avoid a long and prolonged trial. Then, it should be given a classification and an explanation of the meaning of the words, "property that has not been charged" as stated in Article 38 B paragraph (1). What must be straightened out and understood that the purpose of the words, "property that has not been charged" is in

\footnotetext{
${ }^{56}$ MardjonoReksodiputro, submitted to the author on July $4^{\text {th }}, 2012$
} 
the context of the property being discovered at the trial based on the facts of the trial, while the property has not been charged by the public prosecutor, it aims to avoid arbitrariness the authority of law enforcers in confiscating. According to Indriyanto Seno Adji, the philosophy of the sentence "the property of the accused that has not been charged" is"get all the offender's properties" which is commonly known as "impoverishing corruptors". This provision is intended so that there will be no assets left by the perpetrators (allegedly from the proceeds of corruption) to be seized. This is a deviation from the principle of the process of confiscation that requires preprocessual permission in the investigation stage and because the system of reversing the burden of proof of property during the court proceedings, then the policy is given a maxima minima according to explanation $38 \mathrm{~B}$ concerning seizure with the word, "... to the judge with consideration of humanity and life assurance for the defendant." ${ }^{57}$ This is in accordance with the opinion of AndiHamzah, who explained that the purpose of Article 38 $B$ is that when the trial was found the additional assets of the defendant were found, based on this provision the defendant must prove the addition or acquisition of the property. ${ }^{58}$

Furthermore, what must be understood in the reverse proof system is the meaning of a limited and balanced reversal of the burden of proof. Limited means that the reverse proofing system can only be applied to graft offenses related to bribery (Article $12 \mathrm{~B}$ paragraph (1) letter a) and to the seizure of defendant's assets (including husband / wife, children, or corporation) both those who have been indicted and those who not charged (Article $37 \mathrm{~A}$ and Article $38 \mathrm{~B}$ ).

Reversing burden of proof is forbidden to use. Balanced is that in the offense of gratuity related to bribery (Article $12 \mathrm{~B}$ ), the public prosecutor and the defendant both have the obligation to prove but the public prosecutor only proves the gift received by the recipient of the gratuity while the defendant proves that the gratuity is not a bribe, there is no connection with his position and does not conflict with his duties or obligations. Then, in the provisions of Article $37 \mathrm{~A}$ and Article $38 \mathrm{~B}$, the public prosecutor continues to prove the main case negatively (in accordance with the evidence regulated by the Criminal Procedure Code) while the defendant proves that the property in the indictment and which has not been charged by the public prosecutor does not come from a criminal act corruption as charged.

\footnotetext{
${ }^{57}$ Interview with Indriyanto Seno Adji, on July $15^{\text {th }}, 2017$

${ }^{58}$ Interview with AndiHamzah, on July 31 ${ }^{\text {st }}, 2017$
}

According to DjokoSumaryanto, the results of proving the disclosure of deeds and property and wealth (in Article $37 \mathrm{~A}$ and Article $38 \mathrm{~B}$ ) can be classified into several categories, namely: first, the act is corruption and the property comes from corruption; second, his actions are not corruption and his property comes from corruption; third, corruption and property do not originate from corruption and fourthly, their actions are not corruption and their property does not originate from corruption. For this reason, the results of the above evidence are very influential on criminal demands and the application of criminal sanctions relating to corruption and efforts to recover state financial losses. ${ }^{59}$

Thus, according to Guwandi,when implementing the proof reversal verification, the error must be clearly correct so that there is no doubt by using proof measures such as ${ }^{60}$

a. There must be evidence in such a way that if it is measured, it has greater strength in its truth

b. It must be formulated as a level of evidence that will give an impression to the judge of a measure of the level of truth from which the prosecutor / plaintiff fought for.

c. The evidence must really benefit the public prosecutor so that there is no doubt about the defendant's defense.

Based on a theoretical study of the reversal of the burden of proof, according to the "common law" legal system the application of a reversal of the burden of proof is only specific to certain cases relating to corruption offenses, especially against graft offenses related to bribery. Proof of this offense is seen as more complicated and difficult. In addition, corruption is a crime that has a tremendous impact, so that it requires countermeasures from extraordinary juridical aspects and extraordinary legal instruments. ${ }^{61}$ Therefore, specifically against graft offenses relating to bribery of proof of reversal can be applied, because gratuity offenses relating to bribery, including in certain categories, certain cases.

The application of a burden of proof reversal system should be placed in the context of the balance between the two rights. The United States Declaration of 1948 concerning the rights and obligations of people states clearly: "the human rights of a person are limited by the human rights of others, by the security of all people and by a reasonable need for public welfare and democratic progress". ${ }^{62}$ Thus the application of the proof of load

\footnotetext{
${ }^{59}$ DjokoSumaryanto, "Reversal of the burden of proof in taxation corruption," Journal of Justice Vol. 5 No. 1, (Jakarta, 2011), p. 49. ${ }^{60}$ Ibid.

${ }^{61}$ LilikMulyadi, Reversing the Burden of Proof, Op.cit, p. 264. ${ }^{62}$ Financial and Development Supervisory Agency (BPKP), National Corruption Eradication Strategy, (Jakarta: BPKP Education and Training Center, 1999), p. 144., as quoted by ElwiDanil, Ibid, p. 211.
} 
reversal has a logical justification. Then from that, the system of reversing the burden of proof in criminal acts of corruption is a special instrument formed in the framework of verification activities. This system is a deviation from the verification process that has been regulated in the Criminal Procedure Code. It is understandable that the process of establishing the Criminal Procedure Code shows that what we want to fight for is an understanding to see the criminal justice process as based on a due process of law, where the rights of suspects / defendants / convicts are protected and considered part of the rights citizen (civil rights) and because it is part of human rights. In a fair legal process the meaning of the right to independence of a citizen is contained. This meaning is more than just the application of law or regulations in the process of the suspect / defendant. Thus, even though a person has committed a crime, in a fair legal process, his rights as a citizen are not lost. The main milestone of the criminal justice system in the rule of law is the protection of citizens, this is the essence of the correct understanding of a fair legal process.

The deviation of these principles in the application of a burden reversal system of evidence in criminal law has the basis of both theoretical and practical justification, especially in relation to specific criminal laws. One of the characteristics inherent in every special criminal law is that there are provisions that deviate from the general principles of criminal law. The legislators need not hesitate to impose a reversal of the burden of proof in a statutory provision only because in its application there will be deviations from the general principles of criminal law. Isn't the legislator ever brave and shows a firm attitude to make exceptions that urge the principle of legality by formulating positive functions of nature against the material law in corruption laws and urging nonretroactive principles related to the application of the criminal act of terrorism in bomb cases in Bali, even though this has been canceled by the Constitutional Court.

Thus, law enforcement and Indonesian legal politics must not be too fixated with mere human rights considerations that can be exploited by corruptors to take refuge and escape from the reach of criminal law. Moreover Indonesia is not alone in implementing the reversal of the burden of proof in corruption cases, the countries such as; Malaysia, Singapore and Hong Kong have already introduced this system in a law in their country. It is undeniable that this corruption is an extraordinary crime that has violated the interests of many people so that in handling it, an extraordinary legal instrument is needed. In such a framework of thinking, it means that if there is a deviation from the principle in a special criminal law, then it is legal according to the constitution, because if the law making process is in accordance with the constitutional procedures, whatever is included in it is legal according to the constitution. ${ }^{63}$

However, this reversal of the burden of proof must be kept limited and it must be realized that there has indeed been a principle deviation in the law, so that, the application of a reversal of the burden of proof is not interpreted as a deliberate violation of human rights, but merely the eye is only an exception which is forced to be done with consideration of the existence of fundamental reasons so that the interests of the defendant are in the interests of the public, who both need to be protected by law.

With the consideration and justification in the application of the evidentiary load reversal system as described above, it is necessary to immediately improve the formulation of norms from the articles which regulate the reversal of the burden of proof in the corruption law and make a clear technical guidance in application. Thus, it is expected that the application of a reversal of the burden of proof in practice is not a debate and multiple interpretations so that the proof of reversal burden system is expected to become an "extraordinary instrument" or an extraordinary legal instrument in combating corruption which is an "extraordinary crime" which is finally aims to minimize acts of corruption.

\section{Conclusion}

In order to improve the construction of reverse proof verification in the name of corruption investigation, there are several alternative ideas, namely:

a. Construction of the substance of the law, which directs the formulation of norms of burden of proof upside down with an emphasis on legislation policies in accordance with KAK 2003 as a characteristic of a combination of the "Common law" legal system and the "Civil Law" legal system.

b. Construction of law enforcement structures in Indonesia. The point in this case is to place officials of the Corruption Eradication Commission (KPK) all the way to the regions, especially the provincial areas. This is very important as the Saber PungliInstitution was initially warm but later reverberated. If this is done, at the KPK institution, corruption crimes in Indonesia will be reduced and can be minimized.

c. Construction in community culture. Community culture in this context is the habit of the

${ }^{63}$ LoebyLoqman, Politic Delict in Indonesia, (Jakarta: Ind-Hill Co, 1993) p. 108., as stated by ElwiDanil, Ibid, p. 217 
community in viewing and being permissive to perpetrators of corruption. The society which was initially permissive was less assertive to corruptors, was reconstructed by its perspective by giving massive, structured and systematic education emphasizing that corruption crimes were crimes of humanity that were more evil than war, theft and murder. Because corruption impoverishes society and damages the joints of democratic life and the order of social order in society.

\section{REFERENCES}

[1] Ancel, Marc. Social Defense: A Modern Approach to Criminal Problems, (Routledge \& Kegan Paul, London; 1965)

[2] Chazawi, Adami. The Material and Corruption Criminal Law in Indonesia, (Malang: Bayumedia, 2005)

[3] Financial and Development Supervisory Agency (BPKP), National Corruption Eradication Strategy, (Jakarta: BPKP Education and Training Center, 1999)

[4] Garner, Bryan A. Black's Law Dictionary, Eight Edition, West Publishing CO., United States, 2004.

[5] Haertabti, Evi. Criminal Act of Corruption, (SinarGrafika, 2005)

[6] Hiarriej, Eddy OS. Inverted Proof of Corruption, (Yogyakarta: Fiat Justicia Bulletin, Faculty of Law UGM, 2012)

[7] Hoefnagels, G. Peter. The Others Side of Criminology; An Inversions of the Concept of Crime, (Kluwer-Deventer, Holland, 1973)

[8] Marzuki, Peter Mahmud. Legsl Research (Jakarta: Prenada Media, 2005)

[9] Muladi, Kapita Selekta Criminal Justice System, Board of Publishers of Diponegoro University, Semarang, 1995.

[10] Muladi. The Conditional og Criminal Institution. (Bandung: Alumni, 2002)

[11] Mulyadi, Lilik. Reversing the Burden of Proof, (Sinar Grafika, 2005)

[12] Lopa, Baharuddin. Corruption and Law Enforcement, (Jakarta: PT. Kompas, 2001)

[13] Political and Economic Risk Consultancy Ltd is a consulting company that specializes in examining and reviewing the issues of economic and business levels of countries in Asia. See Elwi Danil, The Concept of Corruption, Crime and Inclusion, (Jakarta: PT. Raja Grafindo Persada, 2011)

[14] Prodjohamidjojo, Martiman. Application of Reversed Proof in Corruption Delict, (Bandung: CV. Mandar Forward, 2001)
[15] Soekanto.S, Introduction to Sociology of Law, (Jakarta: Rajawali Pers, 2008)

[16] Samosir, Djisma, The Criminal Function of Prison in Criminal System in Indonesia(Bandung: Bina, Cipta, 1992)

[17] Sudarto, Law and Criminal Law, (Alumni, Bandung; 1986)

[18] Surakhmad , Winaryo. Legal Research Methods, (Jakarta: RinekaCipta, 2003)

[19] Sumaryanto, Djoko. "Reversal of the burden of proof in taxation corruption," Journal of Justice Vol. 5 No. 1, (Jakarta, 2011)

[20] Soedirjo, Prosecutor and Judge in the Criminal Process, (Jakarta: CV. Akademika Pressido, 1985)

[21] Toegarisman A, Eradicating Corruption in the Efficiency Paradigm, (Jakarta: PT. Kompas Media Nusantara, 2016)

[22] Wiriadinata, Loekman. Reverse Verification Problem in the New Anti-Corruption Bill, Law and Justice Magazine, Number 6 September 1, 1970

[23] Yusuf, Muhammad. "Depriving Corruptor Assets: Solution for Eradicating Corruption in Indonesia". Gramedia, (Jakarta, 2003)

\section{Internet}

[24] Ali, Mahrus. The Progressive Criminal Justice System: Some Alternative in Criminal Law Enforcement, Journal of Law No. 2 Vol. 14: 128. Http://www.e-jurnal.com/2013/12/sistem-pidanaprogressive-.html. (Accessed on September 29th 2015 at 2:35 p.m.)

[25] Indonesia Corruption Watch (ICW) 2016 Annual Report, "Sowing the Spirit of Anti Corruption" (online), http://www.antikorupsi.org/, accessed on May $25^{\text {th }}, 2017$ 